\title{
IMPACT OF FISH PROCESSING BY-PRODUCT AMENDMENT ON SOIL PROPERTIES
}

\author{
Rimantas VAISVALAVIČIUS, Department of Agroecosystems and Soil Sciences, Faculty of Agronomy, Vytautas Magnus \\ University, K. Donelaičio g. 58, 44248 Kaunas, Lithuania, rimantas.vaisvalavicius@ vdu.lt (corresponding author) \\ Rūta DROMANTIENE். Department of Agroecosystems and Soil Sciences, Faculty of Agronomy, Vytautas Magnus University, K. \\ Donelaičio g. 58, 44248 Kaunas, Lithuania, ruta.dromantietiene@ vdu.lt \\ Irena PRANCKIETIENĖ. Department of Agroecosystems and Soil Sciences, Faculty of Agronomy, Vytautas Magnus University, \\ K. Donelaičio g. 58, 44248 Kaunas, Lithuania, irena.pranckietiene@ vdu.lt \\ Jūratė ALEINIKOVIENĖ. Department of Agroecosystems and Soil Sciences, Faculty of Agronomy, Vytautas Magnus University, \\ K. Donelaičio g. 58, 44248 Kaunas, Lithuania, jurate.aleinikoviene@ vdu.lt
}

\begin{abstract}
A pot experiment was carried out at the Vytautas Magnus University Agriculture Academy in Lithuania to examine the possibilities of fish processing wastes to improve soil properties. The fish bones powder (FBP) was mixed with the soil, it was placed into the special vegetative pots of 51 in volume up to the thickness of $25 \mathrm{~cm}$. The soil type was Endocalcaric Endogleyic Luvisol (WRB 2014, update 2015) and according to granulometric composition was medium heavy loam. The experiment has designed in 4 variants and 6 replications. Soil samples were collected from the substrates in the vegetative pots 360 days (twelve months) after the application of fish processing by-products.

The results obtained show that FBP application has significantly influenced the increase of organic carbon, available phosphorus, potassium and calcium contents in tested soil. The amount of FBP application didn't show any noticeable impact on soil $\mathrm{pH}$ value, magnesium and sulphur content in medium heavy loam soil. Although the total nitrogen and mineral nitrogen contents have increased in soil a significant changes were found only after use of $6.5 \mathrm{tha}^{-1} \mathrm{FBP}$ rate.

The FBP application has significantly influenced the increase of microbiota abundance, microbial biomass $\mathrm{C}$ and microbial biomass $\mathrm{N}$ in tested soil. The microbial biomass $\mathrm{C}$ and $\mathrm{N}$ directly depended on the (FBP) rate.
\end{abstract}

Keywords: fish by-products; soil amendment; soil chemical and biological properties

\section{INTRODUCTION}

Sustainable management of food waste is one of the most important issues facing the world today (Garcia-Garcia et al., 2017). The use of organic wastes in agriculture provides the opportunity to simultaneously increase soil productivity and contribute to the sustainable management of organic waste (Eden et al., 2017). Depending on the type of transformation, the waste may represent between 30 and $45 \%$ of the initial weight of the product (Illera-Vives et al., 2015).

Fish waste may be processed for food, feed, technical and pharmaceutical purposes. Fish waste that does not meet relevant standards for food or feed, may be used for energy production or fertilizers (Ghaly et al., 2013; Ahuja et al., 2020). Many organic wastes contain nutrients and organic matter that may benefit plant growth and soil productivity. Recycling these materials onto land captures nutrients that would otherwise be lost, and helps sustain our resource base (Chatterjee et al., 2017). Fish waste can be processed into stabilized liquid or solid forms of fertilizers and be combined with other materials to produce fish compost or applied as a substrate in anaerobic digestion (Ahuja et al., 2020).

The fisheries wastes contain nitrogen, phosphorus, potassium, calcium, magnesium, sulfur and microelements making it an excellent broad-based organic fertilizer (Illera-Vives et al., 2015; Radziemska et al., 2019). Numerous studies have been carried out around the world confirming that the use of fish waste can not only improve the physical and chemical properties of the soil, but also increase the productivity of plants (Abbasi et al., 2006; Mondini et al., 2008; Pranckietienè et al., 2013; Thendral Hepsibha, Geetha, 2017; Radziemska et al., 2019). Studies have shown that the use of fish waste may potentially help to improve or sustain soil health at relatively low application rates, through stimulating biological activity, enhancing nutrient and carbon cycling in the soil and potentially increasing the amount of organic carbon in the soil (Mondini et al., 2008; Tahat et al., 2020). Studies have proven that fish waste products improve soil microbiological properties (Doran, Zeiss, 2000; Leskovar et al., 2016). Microbial communities contribute to fundamental processes that provide stability and productivity of agroecosystems (Meena et al., 2016).

Copyright (C) 2021 The Authors. Published by Vytautas Magnus University. This is an open-access article distributed under the terms of the Creative Commons Attribution License (CC BY 4.0), which permits unrestricted use, distribution, and reproduction in any medium, provided the original author and source are credited. 
The aim of this work is to analyze and identify changes in agrochemical soil characteristics and soil microbiota biomass properties 12 months after the fish bones powder application.

\section{MATERIALS AND METHODS}

Soil characteristics. The amount of soil necessary for the experiment of amendment with fish processing byproducts was collected from the plowing soil layer (Ap horizon) of the Endocalcaric Endogleyic Luvisol at the Pomological Garden of VMU Agriculture Academy. Soil texture was defined as medium heavy loam with $\mathrm{pH}_{\mathrm{KCl}} 6.7$, concentration of organic $\mathrm{C}-8.81 \%$, total nitrogen $-0.620 \%$ and following concentration of available nutrients: $\mathrm{P}_{2} \mathrm{O}_{5}-$ $104 \mathrm{mg} \mathrm{kg}^{-1}, \mathrm{~K}_{2} \mathrm{O}-49 \mathrm{mg} \mathrm{kg}^{-1}, \mathrm{Ca}-7820 \mathrm{mg} \mathrm{kg}{ }^{-1}, \mathrm{Mg}-652 \mathrm{mg} \mathrm{kg}^{-1}, \mathrm{~S}-3.6 \mathrm{mg} \mathrm{kg}^{-1}$.

Potting experiment design. Fish bones in a powder form (FBP) have been received from the Nutrimar AS (Norway) company and contained essential amounts of macro and micro elements, including: total N $64040 \mathrm{mg} \mathrm{kg}^{-1}$; total P 100223 $\mathrm{mg} \mathrm{kg}{ }^{-1}$; total $\mathrm{K} 1750 \mathrm{mg} \mathrm{kg}^{-1}$; Ca $12 \%$; Mg 0,29\%; S 2,93 $\mathrm{mg} \mathrm{kg}^{-1}$. Fish bones powder was dried at $105^{\circ} \mathrm{C}$ and milled to $1.5 \mathrm{~mm}$ size particles to get a suitable form to apply in the soil. FBP was mixed with the soil and placed into vegetative pots of 51 in volume up to the soil thickness reached $25 \mathrm{~cm}$. The effect of increasing FBP doses (respectively, 0; 2.5; 4.5; $6.5 \mathrm{t} \mathrm{ha}^{-1}$ or $0 ; 18 ; 32 ; 46 \mathrm{~g}$ of fish bones powder into the vegetative pot) was compared to the control treatment (without any fertilization). The moisture of substrates was $70 \%$ of water holding capacity. Vegetative pots have been transported into the open environment to create outdoor conditions as natural for arable soil in the selected locality. The potting experiment has been implemented in 6 replicates.

Soil sampling and analysis. Soil samples were collected from the substrates in the vegetative pots 360 days (twelve months) after the application of fish processing by-products. Substrates from each vegetative pot were mixed and homogenized in a separate vessel. Then about $150 \mathrm{~g}$ soil was collected from each pot and used for the analysis of soil chemical microbiological properties. Soil $\mathrm{pH}$, concentration of organic $\mathrm{C}$ and total $\mathrm{N}$, content of mineral $\mathrm{N}$ and available $\mathrm{P}_{2} \mathrm{O}_{5}, \mathrm{~K}_{2} \mathrm{O}, \mathrm{Ca}, \mathrm{Mg}$ and $\mathrm{S}$ have been analyzed in the Agrochemical Research Laboratory of the Lithuanian Research Centre for Agriculture and Forestry.

For the evaluation of microbial abundance, 10 grams of each soil sample were added to $95 \mathrm{~mL}$ of $0.1 \%$ (w/v) solution of sodium pyrophosphate. After homogenization for $30 \mathrm{~min}$, the solution was decimally diluted $\left(10^{-1}\right.$ to $\left.10^{-7}\right)$ and aliquots of the resulting solutions were plated on agarised nutrient media (Plate-Count-Agar/standard methods agar (Annand et al., 2003). After incubation at 25 or $30^{\circ} \mathrm{C}$, for up to 10 days, the colony forming units (CFU) were counted. Soil $\mathrm{C}_{\text {mic }}$ and $\mathrm{N}_{\text {mic }}$ were determined by the chloroform fumigation extraction method (Brookes et al., 1985; Vance et al., 1987). $\mathrm{C}_{\text {mic }}$ was calculated from the flush in $\mathrm{K}_{2} \mathrm{SO}_{4}$ - extractable organic $\mathrm{C}$ following $\mathrm{CHCl}_{3}$ - fumigation with a proportionality factor of 0.38 . Total $\mathrm{N}$ in the extracts was determined by an automatic procedure and $\mathrm{N}_{\text {mic }}$ was calculated from the flush in $\mathrm{K}_{2} \mathrm{SO}_{4}$ - extractable total $\mathrm{N}$ following $\mathrm{CHCl}_{3-}$ fumigation with a proportionality factor of 0.54 .

Statistical analysis. The data were statistically processed using the analysis of variance (ANOVA). The significant differences between the means were established by the least significant difference at a significance level of $p \leq 0.05$ (Raudonius, 2017). Data of microbiological analysis were systemized and analysed using the computer software Microsoft Excel, 2010 and statistical software Statistics 7.0 and SPSS 10.0. Correlation coefficients and relationships between the indicators tested were determined using the software STATISTICA 7 (Hill, Levicki, 2005).

\section{RESULTS AND DISCUSSION}

After analyzing the data of agrochemical studies of the soil after 12 months it was observed that FBP did not affect soil $\mathrm{pH}$ (Table 1). However, the product used had a crucial effect on the organic $\mathrm{C}$ changes in the soil. Soil organic carbon has increased significantly by $7.13-21 \%$ depending on the applied FBP rate. This was confirmed by the performed correlation regression analysis (Fig. 1), since a reliable linear equation was obtained: $y=8.5469+0.2957 x\left(R^{2}=0.958\right.$; $\mathrm{P} \leq 0.05)$. Illera-Vives with co-authors (2015) argues that $\mathrm{C}$ mineralization in seaweed and fish waste compost was slow because the organic matter in the compost was very stable and its amount in the soil depended on the rate of fertilizer used. Asare (2019) argues that significant effects of bone meal were observed on organic matter content.

In fact, the largest amount of total nitrogen was found in soil that was fertilized with a maximum FBP rate of 6.5 $\mathrm{t} \mathrm{ha}^{-1}$. Very similar changes in the soil occurred after the study of the content of mineral nitrogen. A significant increase in soil mineral nitrogen content was also found with fertilization using a maximum FBP rate of $6.5 \mathrm{t} \mathrm{ha}^{-1}$ (Table 1).

Table 1. Soil chemical properties in fish bones powder (FBP) treatments in potting experiment

\begin{tabular}{|c|c|c|c|c|c|c|c|c|c|}
\hline \multirow{2}{*}{$\begin{array}{c}\text { Treatment } \\
\mathrm{t} \mathrm{ha}^{-1}\end{array}$} & \multirow[t]{2}{*}{$\mathrm{pH}$} & Organic C & Total N & Mineral N & $\mathrm{P}_{2} \mathrm{O}_{5}$ & $\mathrm{~K}_{2} \mathrm{O}$ & $\mathrm{Ca}$ & $\mathrm{Mg}$ & $\mathrm{S}$ \\
\hline & & \multicolumn{2}{|c|}{$\%$} & \multicolumn{6}{|c|}{$\mathrm{mg} \mathrm{kg}^{-1}$} \\
\hline Control & 6.8 & 8.55 & 0.647 & 46.55 & 101 & 50 & 8176 & 668 & 3.1 \\
\hline 2.5 & 6.8 & $9.16^{*}$ & 0.635 & 46.19 & $596 *$ & 56 & 9100* & 706 & 2.9 \\
\hline 4.5 & 6.8 & $10.12 *$ & 0.649 & 49.98 & $419^{*}$ & $59 *$ & $10086^{*}$ & 742 & 2.6 \\
\hline 6.5 & 6.8 & $10.35^{*}$ & $0.712^{*}$ & $65.28 *$ & $577 *$ & $60 *$ & $9424 *$ & 706 & 2.9 \\
\hline
\end{tabular}

Note: $*$ - significant at $\mathrm{p} \leq 0.05$

Analysis of total nitrogen and mineral nitrogen in the soil in other variants did not show significant changes. Our previous experiment showed that the amount of mineral nitrogen in the soil of all treatments was significantly higher than 
in the control after 1 and 4 months after the application of the FBP (Pranckietiene et al., 2013). It is likely that in this study, 12 months after the inclusion of FBP and without growing the plants, mineral nitrogen was transformed into other forms of nitrogen (evaporated or leached).

The scientific literature states that fish waste products are rich in $\mathrm{P}, \mathrm{K}, \mathrm{Ca}, \mathrm{Mg}$ and microelements (Illera-Vives et al., 2015; Radziemska et al., 2019). The soil was moderately rich in phosphorus prior to FBP incorporation. Studies have shown that the application of different FBP rates has increased available phosphorus content in soil, respectively: 5.9 times after FBP $2.5 \mathrm{t} \mathrm{ha}^{-1}$ was used; 4.1 times after FBP $4.5 \mathrm{t} \mathrm{ha}^{-1}$ was used and 5.7 times after FBP $6.5 \mathrm{t}^{-1}$ was used. This shows that the phosphorus present in the FBP product easily migrates into the soil solution and remains in it for a long time. This was confirmed also by correlation regression analysis. A quadratic equation was obtained: $\mathrm{y}=$ $137.1+175 x-17.7 x^{2}\left(R^{2}=0.727 ; P \geq 0.05\right)$. Silva et al., (2016) stated that the use of organic amendments increases $P$ solubility, which could respond to an effect of organization of $\mathrm{P}$ associated with biological activity and formation of a complex of organic compounds.

The content of mobile potassium in the soil was low before fertilization. The use of the investigated measure increased the amount of available potassium in the soil and a significant increase of this indicator was found when fertilizing 4.5 and $6.5 \mathrm{t} \mathrm{ha}^{-1}$ FBP. Larkin (2020) found that when fishmeal was used to fertilize the soil, the amount of potassium in the soil also increased significantly. Correlation regression analysis showed that the amount of potassium directly depends on the amount of FBP used. The results obtained are best reflected in the resulting linear equation: $y=$ $51+1.56 x\left(\mathrm{R}^{2}=0.999 ; \mathrm{P} \leq 0.05\right)$.

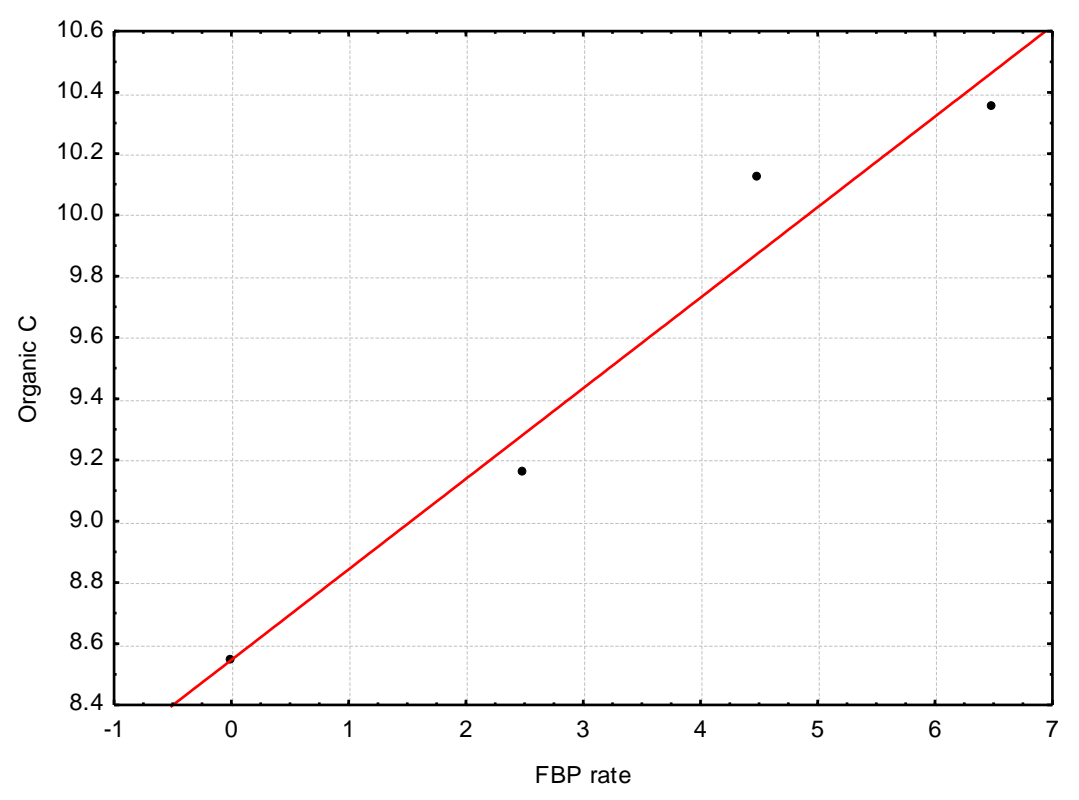

Figure 1. The relationship between organic carbon $(\mathrm{y}, \%)$ and fish bones powder (FBP) content

Studies have shown that the amount of $\mathrm{Ca}$ in the soil also significantly increased by $11.3-23.4 \%$ after the application of FBP. Correlation regression analysis showed that Ca content in soil increases with the increase of FBP content in soil $\left(\mathrm{y}=8096+704 \mathrm{x}-74.2 \mathrm{x}^{2} ; \mathrm{R}^{2}=0.889 ; \mathrm{P} \leq 0.05\right)$. $\mathrm{R}$. Larkin (2020) showed that Fish meal increased Ca content in soil more effectively compared to compost and mineral fertilizers.

$\mathrm{Mg}$ content in soil increased from 38 to $74 \mathrm{mg} \mathrm{kg}^{-1}$ however these changes were insignificant. According to Larkin (2020) fish meal significantly increased the amount of $\mathrm{Mg}$ in the soil. Vaisvalavičius et al. (2014) found a significant increase of $\mathrm{Mg}$ amount in the soil after 4 months when fish bones were applied at the $1-5^{\circ} \mathrm{C}$ temperature regime. Sulfur is also a vital element for plants, being part of some amino acids and involved in the process of photosynthesis (Zhao et al., 2002). However, the FBP product used in this experiment did not affect sulfur changes in the soil.

Soil microbial abundance could be the key in determining the degree of soil quality (Stevenson, Cole, 1999). Enzyme activities have been associated as indicators of biogeochemical cycles, degradation of organic matter, soil remediation processes, thus, in complex with physical or chemical properties can indicate the soil quality. The FBP application has significantly influenced the increase in microbiota abundance in soils (Table 2). The abundance of microbiota has been significantly increasing along with fish bones application rate, as from 2400 to 12000 thousand CFU $\mathrm{g}^{-1}$. The data of the correlation regression analysis showed very strong correlations between the abundance of microbiota and FBP rate $\left(\mathrm{y}=-312.7+1687.7 \mathrm{x} ; \mathrm{R}^{2}=0.999 ; \mathrm{P} \leq 0.05\right)$.

The mean values for microbial biomass $\mathrm{C}$ ranged from 119.7 to $305.5 \mu \mathrm{g} \mathrm{C} \mathrm{g}^{-1}$ in soil (Table 2). The results of the soil microbial biomass analysis indicate that the amended soils (FBP) contained significantly $1.6-2.6$ times higher microbial biomass $\mathrm{C}$ than in the Control pots. Correlation regression analysis confirmed that the amount of microbial biomass $\mathrm{C}$ depends on the amount of FBP incorporated into the soil $\left(\mathrm{y}=120.4+30 \mathrm{x} ; \mathrm{R}^{2}=0.981 ; \mathrm{P} \leq 0.05\right)$. 
Table 2. Soil microbiota mean total abundance and soil microbiota biomass $\mathrm{C}$ and $\mathrm{N}$ under fish bones powder (FBP) treatments in potting experiment

\begin{tabular}{|c|c|c|c|}
\hline \multirow{2}{*}{ Treatment } & $\begin{array}{c}\text { Abundance of microbiota } \\
\pm \text { SD }\end{array}$ & $\mathrm{C}$ & Microbiota biomass \pm SD \\
\cline { 3 - 4 } & thousand CFU g $^{-1}(\mathrm{DM})$ & $\mu \mathrm{g} \mathrm{C} \mathrm{g}^{-1}$ & $\mu \mathrm{g} \mathrm{N} \mathrm{g}^{-1}$ \\
\hline $\mathrm{t} \mathrm{ha}^{-1}$ & $1031.1 \pm 33.3$ & $119.7 \pm 5.8$ & $13.3 \pm 0.6$ \\
\hline Control & $2395.0 \pm 258.2$ & $187.2 \pm 7.1$ & $26.7 \pm 1.0$ \\
\hline 2.5 & $5938.0 \pm 397.8$ & $273.5 \pm 12.4$ & $45.6 \pm 2.1$ \\
\hline 4.5 & $12169.5 \pm 25.3$ & $305.5 \pm 9.2$ & $50.9 \pm 1.5$ \\
\hline
\end{tabular}

Note: $\mathrm{SD}$ - standard deviation of the mean

The same tendencies could be determined by estimating the microbial biomass $\mathrm{N}$ in soil. The mean values for microbial biomass $\mathrm{N}$ ranged from 13.3 to $50.9 \mu \mathrm{g} \mathrm{N} \mathrm{g}^{-1}$ in soils (Table 2). The microbial biomass nitrogen directly depended on the (FBP) rate. This was confirmed also by correlation regression analysis because a statistically reliable linear equation was obtained: $\left.\mathrm{y}=13.4+6.1 \mathrm{x} ; \mathrm{R}^{2}=0.971 ; \mathrm{P} \leq 0.05\right)$.

\section{CONCLUSIONS}

Studies have shown that fish bones powder can improve the agrochemical and microbiological soil properties. The treatment used significantly increases the amount of organic carbon, available phosphorus and potassium contents as well calcium content in the soil. Only the rate of $6.5 \mathrm{t} \mathrm{ha}^{-1}$ fish bones powder significantly increased the amounts of total and mineral nitrogen in the soil. The treatment used did not have a decisive effect on the magnesium and sulfur content of the soil. Fish bones powder application has significantly influenced the increase in microbiota abundance and soil microbiota biomass $\mathrm{C}$ and $\mathrm{N}$.

Acknowledgement. The research leading to these results has received funding form the European Community Seventh Framework Programme FP7/2007-2013 under grant agreement No. 289170 - APROPOS.

\section{REFERENCES}

1. Abbasi P., A., Conn K. L., Lazaroovits G. 2006. Effect of Fish Emulsion Used as a Preplanting Soil Amendment on Verticillium Wilt, Scab and Tuber Yield of Potato. Canadian Journal of Plant Pathology, Vol. 26. pp. 509-518. https://doi.org/10.1080/07060660609507328

2. Ahuja I., Dauksas E., Remme J. F., Richardsen R., Løes A-K. 2020. Fish and fish waste-based fertilizers in organic farming With status in Norway: A review. Waste Management, vol. 115, p. 95-112. https://doi.org/10.1016/j.wasman.2020.07.025

3. Asare W. 2019. Effects of bone meal on physiochemical soil properties of a fertilized reclamation site in Iceland. Final project „UNU Land Restoration Training Programme“, p. 22

4. Chatterjee R., Gajjela S., Thirumdasu R.K. 2017. Recycling of Organic Wastes for Sustainable Soil Health and Crop Growth. International Journal of Waste Resources, Vol. 7, pp.1-8. https://doi.org/10.4172/2252-5211.1000296

5. Dindar E. F., Sagban T. O., Baskaya H. S. 2015. Variations of soil enzyme activities in petroleum-hydrocarbon contaminated soil. International Biodeterioration \& Biodegradation, Vol. 105, pp. 268-275. https://doi.org/10.1016/j.ibiod.2015.09.011

6. Doran J. W., Zeiss M. R. 2000. Soil health and sustainability: Managing the biotic component of soil quality. Applied Soil Ecology, Vol. 15, pp. 3-11. https://doi.org/10.1016/S0929-1393(00)00067-6

7. Eden M., Gerke H. H., Houot S. 2017. Organic waste recycling in agriculture and related effects on soil water retention and plant available water: a review. Agronomy for Sustainable Development, Vol. 37, pp. 1-21. https://doi.org/10.1007/s13593$\underline{017-0419-9}$

8. Garcia-Garcia G., Woolley E., Rahimifard S., Colwill J., White R., Needham L. 2017. A methodology for sustainable management of food waste. Waste \& Biomass Valorization, Vol. 8, pp. 1-19 https://doi.org/10.1007/s12649-016-9720-0

9. Ghaly A.E., Ramakrishnan V.V., Brooks M.S., Budge S.M., Dave D. 2013. Fish processing wastes as a potential source of proteins, amino acids and oils: A critical review. Journal of Microbial \& Biochemical Technology, Vol.5, pp. 107-129. https://doi.org/10.4172/1948-5948.100011

10. Illera-Vives M., López-Fabal A., López-Mosquera, M. E., Ribeiro 2015. Mineralization dynamics in soil fertilized with seaweed-fish waste compost. Journal of the Science of Food and Agriculture, Vol. 95 (15), pp. $3047-54$. $\underline{\text { https://doi.org/10.1002/jsfa.7207 }}$

11. Illera-Vives M., Labandeira S.S., Brito L.M., López-Fabal A., López-Mosquera M.E. 2015. Evaluation of compost from seaweed and fish waste as a fertilizer for horticultural use. Scientia Horticulturae, Vol. 186, pp. $101-107$. https://doi.org/10.1016/j.scienta.2015.02.008

12. IUSS Working Group WRB. 2015. World Reference Base for Soil Resources 2014, update 2015. International soil classification system for naming soils and creating legends for soil maps. World Soil Resources Reports No. 106. FAO, Rome.

13. Larkin R. P. 2020. Effects of Selected Soil Amendments and Mulch Type on Soil Properties and Productivity in Organic Vegetable Production. Agronomy, Vol. 10, ID795. https://doi.org/10.3390/agronomy10060795

14. Leskovar D., Othman Y., Dong, X. 2016. Strip tillage improves soil biological activity, fruit yield and sugar content of triploid watermelon. Soil and Tillage Research, Vol. 163, pp. 266-273. https://doi.org/10.1016/j.still.2016.06.007 
15. Meena R., Bohra J., Singh S., Meena V., Verma J., Verma, S., Sihag S. 2016. Towards the prime response of manure to enhance nutrient use e_ciency and soil sustainability a current need: A book Review. Journal of Cleaner Production, Vol. 112, pp. 1258-1260. https://doi.org/10.1016/j.jclepro.2015.05.122

16. Mondini C, Cayuela M., Sinicco T, Sanchez-Monedero M., Bertolone E, Bardi L. 2008. Soil Application of Meat and Bone Meal. Short-term Effects on Mineralization Dynamics and Soil Biochemical and Microbiological Properties. Soil Biology and Biochemistry, Vol. 40, pp. 462-474. https://doi.org/10.1016/j.soilbio.2007.09.010

17. Pranckietienė I., Vaisvalavičius R., Dromantienė R., Aleinikovienė J. Assessment of 2013. Fish Processing Wastes for the Improvement of Soil Properties. Proceedings of Rural development 2013, Vol. 6, b. 3, p. 412-417.

18. Radziemska M., Vaverkova M.D., Adamcova·D., Brtnickż M., Mazur Z. 2019. Valorization of Fish Waste Compost as a Fertilizer for Agricultural Use. Waste and Biomass Valorization, Vol. 10, pp. 2537-2545. https://doi.org/10.1007/s12649-018$\underline{0288-8}$

19. Silva D.J., Bassoi L.H., da Rocha M.G., Da Silva A. O., Dall'Igna Deon M.. 2016. Organic and nitrogen fertilization of soil under 'Syrah' grapevine: Effects on soil chemical properties and nitrate concentration. Revista Brasileira de Ciência do Solo, Vol. 40, ID 150073. https://doi.org/10.1590/18069657rbcs20150073

20. Stevenson F.J., Cole M.A. 1999. Cycles of Soil. - 2 nd ed., Wiley, NY, USA.

21. Tahat M. M., Alananbeh K. A., Othman Y. I., Leskovar D. 2020. Soil Health and Sustainable Agriculture. Sustainability. Vol. 12(12), pp. 1-26. https://doi.org/10.3390/su12124859

22. Thendral Hepsibha B., Geetha A. 2017. Effect of Fermented Fish waste (Gunapaselam) Application on the Soil Fertility with Special Reference to Trace Elements and the Growth Characteristics of Vigna radiata. International Journal of Agriculture Innovations and Research, Vol. 5, Issue 4, pp. 2319-1473.

23. Zhao F.J., McGrath S.P., Blake-Kalff M.M.A., Link A., Tucker M. 2002. Crop responses to sulphur fertilisation in Europe. Proceedings No. 504. International Fertiliser Society, York. 